\title{
Genesis and identity of Chanco cheese (Chile 1750-1860). A contribution to studies on Appellations of Origin in Latin America
}

\author{
Pablo Lacoste, Diego Jiménez, and Natalia Soto \\ Instituto de Estudios Avanzados, Universidad de Santiago de Chile. Román Díaz 89. Santiago, Chile.
}

\begin{abstract}
P. Lacoste, D. Jiménez, and N. Soto. 2014. Genesis and identity of Chanco cheese (Chile 1750-1860). A contribution to studies on Appellations of Origin in Latin America. Cien. Inv. Agr. 41(3):317-325. The origin of Chanco cheese in Chile, between 1750 and 1860, is discussed. The inventories of eight cheese factories from the 18th and 19th centuries as well as additional documentary sources from the time period are studied. Chanco cheese was a cooked and matured cheese from cow and, mainly, sheep milk. The original productive zone was limited by the Maule and Itata rivers, in the Central Valley. In the 18th and 19th centuries, Chanco cheese was recognized as the best cheese in Chile; its production and marketing were well established during the first two thirds of the19th century, and it commanded good market prices based on its fame. Chanco cheese was eaten throughout almost the entire country, from Copiapó to Valdivia. Chanco cheese was also significantly exported during the middle of the $19^{\text {th }}$ century.
\end{abstract}

Key words: Agrofoods in Chile, Appellations of Origin, Chanco cheese, Geographical Indication.

\section{Introduction}

With cheese consumption at $9.5 \mathrm{~kg}$ per capita $(\mathrm{p} / \mathrm{c})$ per year, Chile is one of the largest consumers in Latin America after Argentina (12 kg p/c), which is similar to Europe and North America $(15 \mathrm{~kg} \mathrm{p} / \mathrm{c})$ but dissimilar to developing countries (less than $1 \mathrm{~kg} \mathrm{p} / \mathrm{c}$ ). Argentina leads the region in cheese production (500,000 tons per year), but production in Chile is growing at a good rate; 53,075 tons were produced in 2002, which rose to 61,745 in 2007 and 89,046 in 2013 (Odepa, 2014). Chanco cheese played a significant role in the Chilean diet during the 20th century. Nevertheless, the 20th century's Chanco cheese organoleptic characteristics are

Received May 13, 2014.Accepted October 30, 2014. Corresponding author: pablo.lacoste@usach.cl not the same characteristics as during its birth and establishment as a famous and prestigious product. Currently, Chanco cheese has neither a Geographical Indication (GI) nor an Appellation of Origin (AO).

$\mathrm{AO}$ and GI development has enhanced the identity and economic value of regional farming food products, mostly in Europe (Ribeiro de Almeida, 2010). However, in Latin America, few products have an established DO or GI; the few exceptions include Pisco in Peru and Chile (Lacoste et al., 2014). However, a considerable potential exists for development of an AO and a GI in Latin America to enhance the identity, quality and value of the products (Pszczólkowski, 2014), especially famous products, such as Chanco cheese in Chile, which requires a historical study on the product. 


\section{Materials and methods}

In our inquiry into the nature of Chanco cheese production in Chile during its origin, we used historical methods (critically heuristic). To understand Chanco cheese production, original Archivo Nacional documents were consulted, particularly the Judicial and Notarial collections of Talca and Cauquenes. To understand Chanco cheese distribution in Chile, the judicial and notarial collections of Colchagua, Santiago, San Felipe and La Serena were revised. Works from chroniclers, travelers and observers of the time were also revised. On this basis, we have advanced there construction of the production zone boundaries, the nature of Chanco cheese, its distribution in the region, and its prices.

\section{Results and discussion}

Based on specialized literature from the 18th and 19th centuries, Chanco cheese was valued. The expelled Jesuit Juan Ignacio Molina, who is commonly referred to as Abate Molina and native to the Chanco region, noted Chanco cheese in his work during his exile in Italy, both in his original work written in Italian (1776) and in the Spanish version of 1810, wherein he states the following. "The cheeses made in Chile are exquisite, but singularly those manufactured in a town on the Maule marshes, called Chanco, which neither in goodness nor in size are less than the cheeses of Lodi" (Molina, 1987). These references have been noted by historians devoted to studying foods in colonial Chile (Pinochet de la Barra, 1979); they agree and have noted the superiority of Chanco cheese in Chile. Further, a general study on national economic production by Claudio Gay at the request of the Chilean government confirmed this assessment (Gay, 1862). Chanco cheese' snotoriety was also recognized by the Sociedad Nacional de Agricultura $(1869,1870)$ and Bauer (1994). The specialized literature agrees that Chanco cheese garnered a high value and notoriety in Chile during the 18th and 19th centuries.
Even though authors consistently recognize that Chanco cheese was famous, they have not progressed in its characterization. Abate Molina associated it with cow's milk; Gay, 1862 defined it as a "buttery cheese"; and the "Boletin SNA" associated it with grass in the Maule region. In addition to these partial references, the original boundaries of the productive area or the main characteristics of this cheese have not been systematically studied. The presence of the two elements is a key factor is collecting the minimum data required to construct a Chanco cheese AO. Thus, the main objectives of this research paper are, on one hand, to discern the geographical boundaries of the aforementioned cheese. On the other hand, the authors seek to determine the main characteristics of the original Chanco cheese-making process.

\section{The Chanco cheese production zone}

The original Chanco cheese production zone was the area referred to as "Maule Sur", which is located between the rivers Maule and Itata (Retamal, 2006). The Chanco Chapel, which is dedicated to the Virgin Mary, was built in this area, and the Chanco curacy was organized around the chapel, which is an evangelization and pilgrimage center. As was typical in colonial times, the market and socioeconomic activities revolved around the Chapel. The Chapel and Chanco curacy became points of reference in Maule Sur. In the 18th century, several Partido del Maule (Maule District) neighbors requested burial in the Chanco Chapel.

The Villa de Cauquenes founding (9-5-1742) began the process of concealing the original Chanco territory; it also led to the organization of the Cauquenes curacy, which replaced the Chanco curacy. The new point of reference in the Maule Sur zone became Cauquenes, which is also referred to as "ex Chanco" (Cobos, 1989). One century later, the small village of Chanco (1859), which is $30 \mathrm{~km}$ northeast of Cauquenes and at 
the base of the present Municipio de Chanco, is currently limited to a small commune of $530 \mathrm{~km}^{2}$ and 9,000 inhabitants, which composes less than $1 \%$ of the total population of the Maule Region. Therefore, the significance of the current small commune of Chanco differs from the extensive and influential Chanco curacy during the first half of the $18^{\text {th }}$ century. The process of creating and establishing Chanco cheese did not occur in the current commune of Chanco but in a larger area that stretched between the Maule and Itata rivers from San Javier to the Pacific Ocean.

The economic context of Chanco cheese's rise: cattle raised in the Central Valley

Chanco originated when raising cattle was expanded in the Central Valley, which began in the $17^{\text {th }}$ century and was established in the 18th to satisfy high demand in the Potosí markets, which consumed animal products from the Central Valley, including dried meat (charqui), tanned leather, lard, and wool fabrics (Retamal, 2006).

Sheep breeding led the cattle expansion in the Central Valley. As determined by Retamal (2006) in Maule Sur (between the rivers Maule and Itata) in the $17^{\text {th }}$ century, the 19 ranchers included a total of 56,174 heads; sheep represented the majority $(29,254$ heads, $52 \%)$. This trend intensified in the following century. In fact, for the first half of the $18^{\text {th }}$ century, the Maule district registers documented 153,242 cattle heads, 87,459 of which were sheep (57\%). These data were produced by Barra (2006) and demonstrate the increase in sheep cattle in the region (see Table 1).
The table shows the progress of cattle-raising activity in the Maule zone, which began in the $17^{\text {th }}$ century and increased in the $18^{\text {th }}$ century. The two centuries exhibit exceptional consistency in the types of cattle; in both cases, the most abundant species is sheep, which is followed by goats, collectively accounting for $85 \%$ of the total cattle in the region. Large cattle contributed only the remaining $15 \%$; bovines predominated over equines. Small cattle predominated due to the coastal and interior dry land climate and soil conditions in the Maule zone. Chanco cheese rose in this rural society, which was devoted to cattle raising and where sheep predominated.

\section{Chanco cheese in archives (1773-1821)}

Archives indicate that eight Chanco cheese factories were located between the Maule and Itata rivers. The documents provide information on the number of livestock in each productive center, the type of raw material used, and the prices. For details on the prices, we compared these documents with data from other jurisdictions in the Kingdom of Chile to determine the price variations based on business activity. The information is organized in Table 1.

The Chanco cheese producers in Cauquenes maintained important stock. In total, the eight tambos had $13,047 \mathrm{~kg}$ of cheese with an average of 1,630 $\mathrm{kg}$ for each producer, which supports a commercial production objective. In general, the tambos had between 1300 and $2600 \mathrm{~kg}$ of cheese. It should be noted that modern refrigeration methods did not exist; thus, the producers must have been alert to

Table 1. Cattle registered in the Maule zone. The table is based on Retamal (2006) and Barra (2006).

\begin{tabular}{|c|c|c|c|c|c|c|c|c|c|c|}
\hline & \multicolumn{10}{|c|}{ Cattle registered in the Maule zone } \\
\hline & \multicolumn{2}{|c|}{ Sheep } & \multicolumn{2}{|c|}{ Goats } & \multicolumn{2}{|c|}{ Bovines } & \multicolumn{2}{|c|}{ Equines } & \multicolumn{2}{|c|}{ Total } \\
\hline & Number & $\%$ & Number & $\%$ & Number & $\%$ & Number & $\%$ & Number & $\%$ \\
\hline 17 th & 29,254 & 52 & 17,678 & 31 & 7,168 & 12 & 2,073 & 3 & 56,174 & 100 \\
\hline 18th & 87,459 & 57 & 42,122 & 27 & 14,682 & 9 & 9,979 & 5 & 153,242 & 100 \\
\hline
\end{tabular}

The registers of the 17 th century correspond to 19 farmers in Maule Sur; the data for the 18th century comprise the "Partido del Maule" between 1726-1750. 
prevents poiling the cheese during transportation and marketing. Thus, the Cauquenes tambos took care in producing cooked and ripe cheese, which was the basis for the Chanco cheese quality.

Chanco cheese included variable sizes and aging; it could be large, regular, and small. Standardized measurements did not exist, but the large cheese samples could weigh approximately $46 \mathrm{~kg}$, as recorded for the Fermín de la Barra "tambo". Francisco Opazo produced 34 large cheeses as well as 114 regular and small cheeses. The cheeses could be produced in the same year or aged. In his house at the Villa de Chanco, Pascual Valdebenito had $598 \mathrm{~kg}$ of aged cheese, 1,334 from the "present harvest" and an additional $414 \mathrm{~kg}$ of undefined cheese.

The cheese factories were not isolated facilities but part of a productive chain that included other activities, such as raising cattle, a textile industry, and viticulture. The cheese producers were also viticulturists, who maintained small vineyards with between 1,000 and 21,000 plants; at the time, they grew between 1,500 and 2,000 plants per "cuadra" (125.39 m), which were small units between 1 and 10 hectares. In turn, the viticulturists generally maintained their own cellars and winepresses for wine production. Six of the eight producers maintained their own cellars. These cellars included a 1,039.5 arrobas vessel capacity, which is equivalent to approximately 38,000 liters of wine, with an average of 200 "arrobas" in vessels (7200 liters). Therefore, Chanco cheese and grape vines as well as wine culture were linked.

The original Chanco cheese: sheep and cow milk

In the traditional milk industry, cows were most important followed by goats and then by sheep (Rigaux, 2008). However, in certain Europe regions, cheese was traditionally produced using sheep milk, such as Roquefort in France and
Manchego in Spain (Rigaux, 2008). The Spanishcriollo cheese makers in Chile combined the two Europe an traditions by producing Chanco cheese using sheep and cow milk.

The eight Chanco cheese producers had 5,148 sheep with an average of 643.5 heads per producer. They also raised bovine cattle; six of the eight producers had a total of 769 heads with an average of 128 animals per owner. However, the number of goats was substantially lower; only two of the eight cheese producers had a total of 456 heads. Overall, the eight cheese producers had 6,373 heads of cattle, which included 5,148 sheep (80\%), 769 bovines (12\%) and 456 goats $(7 \%)$.

Chanco sheep adapted better to the vineyard conditions than goats because goats tend to damage the grapevines. The impact of sheep is lower; they also contribute their manure to the vineyard as a natural fertilizer, which is important because all of the Chanco cheese producers grew grapevines. Therefore, the conditions between the sheep and vineyard as well as between the Chanco cheese and Cauquenes wine were harmonious. Moreover, the sheep in the vineyard were controlled because the sheep would otherwise also damage the cultures. Thus, the vineyards were protected by surrounding hedges and palisades.

Table 2 outlines the economic activities of the eight "tambos" that produced Chanco cheese. For raising cattle, sheep substantially predominated over the other types of cattle, both bovine and goat. The main reason for raising sheep was milk production; thus, the sheep milk must have played a central role in cheese production. Making cheese, raising cattle, and making wine were clearly linked, as shown in Table 2 . In turn, the cheese makers were cattle raisers and wine makers with a tendency to specialize, not all of which performed the three activities in the same proportion; certain producers emphasized viticulture, and other producer preferred cheese production. Thus, sheep milk use distinguished Chanco cheese from the remaining regions. 
Table 2. Chanco Cheese Producers from the Maule Region, Chile (1773-1821). The table is based on the quoted primary sources.

\begin{tabular}{|c|c|c|c|c|c|c|c|}
\hline \multirow[b]{3}{*}{ Producer / Place } & \multicolumn{7}{|c|}{$\begin{array}{c}\text { Chanco cheese producers } \\
\text { (Maule Region- Chile, 1773-1821) }\end{array}$} \\
\hline & \multirow[b]{2}{*}{ Year } & \multicolumn{2}{|c|}{ Vineyards } & \multicolumn{3}{|c|}{ Cattle } & \multirow[b]{2}{*}{$\begin{array}{l}\text { Cheese in cellars } \\
(\mathrm{kg})\end{array}$} \\
\hline & & $\begin{array}{c}\text { Vine-yard } \\
\text { plants }\end{array}$ & $\begin{array}{c}\text { Cellar } \\
\text { Vessel capacity }\end{array}$ & $\begin{array}{l}\text { Ovine } \\
\text { Head }\end{array}$ & $\begin{array}{l}\text { Bovine } \\
\text { Head }\end{array}$ & $\mathrm{O} / \mathrm{B}$ ratio & \\
\hline $\begin{array}{l}\text { 1. F. de la Barra } \\
\text { Villa de Cauquenes }\end{array}$ & 1773 & 19,000 & $478 @$ & 396 & 296 & 1.33 & 276 \\
\hline $\begin{array}{l}\text { 2. P. Carrasco } \\
\text { Estancia Tapar }\end{array}$ & 1805 & 1,000 & $40 @$ & 683 & 34 & 20.0 & 1,978 \\
\hline $\begin{array}{l}\text { 3-J. Mena } \\
\text { Pje A. Sánchez }\end{array}$ & 1811 & 4,676 & $\mathrm{~s} / \mathrm{d}$ & 150 & 20 & 7.5 & 1,380 \\
\hline $\begin{array}{l}\text { 4-Pedro Aravena } \\
\text { Nirivilo }\end{array}$ & 1814 & 14,810 & $\mathrm{~s} / \mathrm{d}$ & 1564 & 270 & 5.79 & 2,576 \\
\hline $\begin{array}{l}\text { 5-P. Valdebenito } \\
\text { Chanco - Curañipe - } \\
\text { Itata }\end{array}$ & 1814 & 8,000 & $70 @$ & 383 & 0 & 383.0 & 1,352 \\
\hline $\begin{array}{l}\text { 6-V. Aguilera } \\
\text { Asiento de } \\
\text { Codellina }\end{array}$ & 1818 & 11,236 & 61 1⁄2@ & 622 & 8 & 77.7 & 713 \\
\hline $\begin{array}{l}\text { 7-F. Opazo } \\
\text { Asiento de Numen }\end{array}$ & 1820 & 21,692 & $250 @$ & 864 & 134 & 6.44 & 2,564 \\
\hline $\begin{array}{l}\text { 8-José Bobadilla } \\
\text { Estancia Yale Yale }\end{array}$ & 1821 & 5,050 & $140 @$ & 486 & 7 & 69.4 & 2,208 \\
\hline Total & & 85,464 & 10391⁄2@ & 5148 & 769 & 6.69 & 13,047 \\
\hline
\end{tabular}

The "arroba" (@) was the unit for measuring liquids and is equivalent to 36 liters.

Sources: 1. De la Barra (1773); 2. Carrasco (1805); 3. Mena (1811); 4. Aravena (1814); 5. Valdebenito (1814); 6. Cáceres (1818); and 7. Opazo (1820). The deposit included 34 large cheeses as well as 114 medium and small cheeses; 8. Bobadilla (1821).

The milk yield for making cheese varies depending on whether the milk is from cows or sheep. Traditionally, for raising cattle, sheep milk included $82.5 \%$ water and $17.5 \%$ dry matter; however, cow milk included $87.5 \%$ water and $12.5 \%$ dry matter. Of the protein mixture used to make cheese, sheep milk included $6.6 \%$ and cow milk included 3.9\% (Rigaux, 2008). Therefore, the sheep milk yield was better for making cheese; one $\mathrm{kg}$ of cheese required between 16 and 18 liters of cow milk and approximately only 9 liters of sheep milk.

The higher sheep milk yield for making cheese was partially compensated by the greater milk productivity per cow head. In traditional milk production, the animals were not specialized, but they fulfilled multiple functions, wherein part of their energy was oriented to ward reproduction and breeding, sheep were valued for wool, and bovines were valued for work. In fertile land, a cow could produce approximately 11 or 12 liters per day (Rigaux, 2008); in poorer land, such as in Castilla or the coastal and interior dry lands of Maule, a cow could produce approximately 6 or 8 liters. Therefore, if cheese was only produced using cow milk, ten heads would be necessary to produce less than one kilogram of cheese. "In Chanco the cheese produced daily by ten good quality a cow during the good season was estimated at two pounds" (BSNA, 1870). On the other hand, after feeding their young for one month, the sheep began a period of approximately three months in which they could produce 75 to 80 liters of milk, which is approximately one liter per day (Rigaux, 2008). Although the cows produced more milk per head than sheep, the greater abundance of sheep would supply the difference.

Table 2 also shows the evolution of the relationship between the two types of milk over time. In the 
$18^{\text {th }}$ century, the F. de la Barra "tambo" had only 1.33 sheep per cow; thus, cow milk predominated in his Chanco cheese, which is consistent with Abate Molina's observations. However, in the $19^{\text {th }}$ century, the "tambos" reduced the proportion of bovines and increased the proportion of ovines. The ratio became 9 or 10 sheep for every cow. Therefore, considering the higher milk productivity of the cows, we conclude that Chanco cheese was produced from approximately equal levels of both milks, and sheep milk predominated due to its higher dry matter content. Moreover, we must consider the organoleptic characteristics of sheep milk, such as its taste and smell, which are clearly stronger than cow milk. Thus, even if Chanco cheese were composed of equal levels of both milks, the milk that provided its character was sheep milk.

Chanco cheese conquered the Chilean market (1770-1860)

Chanco cheeses pread into the consumption markets south and north of the Maule. The consolidation of the "camino real", which connected Santiago and Concepción, facilitated development of a regular land transport system using mules and muleteers (arrieros); this modality connecte driver transport across the Maule River and maritime service to the Talcahuano, Concepción and Coquimbo ports. Thus, the conditions for promoting Chanco cheese distribution in the region were present.

An analysis of the inventories showed that, throughout the Kingdom of Chile, only Cauquenes included cheese factories. In the other Chilean cities, only small quantities of cheese were documented and were exclusively used for domestic consumption. Only the Kingdom of colonial Chile produced cheese for marketing purposes. The Chanco producers generated large quantities for the market comprising the whole Kingdom of Chile, from north to south. In the south, one of the main markets was the Order of San Francisco, which was centered in the Pro- paganda Fide school of Chillán. The Franciscan father srequired cheese to supply the school's demand and for their missions throughout the Diocese of Concepción, which extended to Santa Bárbara, Tucapel and Valdivia; these data were collected by Professor Cristian Leal from the annual accounts of the School of Chillán for the decades 1770 and 1780 (Leal, 2013).

In the $19^{\text {th }}$ century, Chanco cheese spread throughout the national markets and was marketed in the Central Valley as well as the large cities. The notarial archives documented this cheese in Santiago. In the partition of the goods of Pedro Nolasco Arancibia, the notaries documented 360 $\mathrm{kg}$ of Chanco cheese (Arancibia, 1827). Later, in 1845, the inventory of the goods of Francisco Hidalgo documented $90 \mathrm{~kg}$ of Chanco cheese (Hidalgo, 1845). By the middle of the $19^{\text {th }}$ century, the cheese "of Chanco was exported all along the coast and is preferred by the consumers because of its excellent taste" (Gay, 1862). After the internal market was secured, the $\$ 38,432$ cheese was exported during the three-year period 1856-1858, which rose to $\$ 80,592$ in $1866-1868$. In one decade, Chanco cheese export doubled (BSNA, 1870).

\section{The price of Chanco cheese (1800-1845)}

Studies on the price of Chanco cheese indicate its marketing potential, particularly due to the market price difference between the place the cheese was produced and consumed. Thus, it is important to identify the price of Chanco cheese in Cauquenes and in other cities in Chile, mainly Santiago. In the "Partido de Cauquenes" (Cauquenes District), $46 \mathrm{~kg}$ of Chanco cheese was between 2 and 6 reales $(\$ 0.25$ to $\$ 0.75)$, but in the Central Valley, in Santiago and in the Aconcagua Valley, $46 \mathrm{~kg}$ of Chanco cheese was 64 “reales" (\$8.00). This price difference demonstrated the notoriety of Chanco cheese in Chilean society, as Abate Juan Ignacio Molina noted; due to its notoriety, Chanco cheese "always had a higher price than the others" (Gay, 1862). 
The cycle of Chanco cheese's birth and establishment as a product recognized in Chile based on its quality and geographic origin occurred between 1750 and 1860 . After over a century and a half, the effort from the cheese makers in the region originally referred to as Chanco had garnered notoriety in the markets. Throughout Chile, Chanco cheese was recognized as the country's best cheese. This sentiment was articulated by Abate Molina in approximately the middle of the $18^{\text {th }}$ century and was repeated by Claudio Gay in the $19^{\text {th }}$ century; it was shared in the $20^{\text {th }}$ century by historians, such as Bauer, and additional historians interested in Chilean food and gastronomy between the 18 th century and mid-19 $9^{\text {th }}$ century.

From the information collected, Chanco cheese was a cheese produced using sheep or cow milk; the former predominated. Therefore, the raw material for Chanco cheese is related to the $\mathrm{La}$ Mancha and Roquefort cheeses. From a preparation perspective, Chanco cheese was a cooked cheese that ripened over months and could be stored for several years. Thus, based on the cheese categories at the time, Chanco cheese belonged to a group of cooked cheeses, the emblematic product of which was Gruyère cheese in Europe (Rigaux, 2008).

The geographical indications for Chanco cheese are not restricted to the present commune of Chanco but to the region that was referred to as Chanco during the first half of the 18th century, which extended from Maule River to Itata River and from the Central Valley to the Pacific Ocean. It included an extensive territory that comprised approximately $6,000 \mathrm{~km}^{2}$ and currently coincides in part with the province of Cauquenes, which includes dry lands with relatively poor vegetation and is adequate for raising sheep as well as, to a lesser extent, bovines.

The original Chanco cheese was produced using sheep and cow milk in approximately equal parts but was qualitatively predominated by the former due to lower fat content, higher protein content, and organoleptic characteristics (strong taste and smell). The cheese's characteristics are derived from the composition of the production farms, which included good sheep herds. The Chanco cheese producers raised an average of 643 ovines and 96 bovines. Chanco was the only region in the Kingdom of Chile that produced cheeses in large volumes for the market. Chanco cheese earned notoriety and was distributed throughout the markets in the kingdom, from Valdivia to Copiapó. The quality of Chanco cheese was also reflected in its notoriety and price; due to its prestige, the Chilean market was willing to pay slightly more for it. Finally, based on primary and secondary source information on Chanco cheese, we conclude that its prices were the highest and its quality was highly regarded in the Chilean market in 1770-1860.

\section{Acknowledgements}

This study was prepared with financial support from the Comisión Nacional de Investigación Cientifica y Tecnológica (CONICYT) through the Regular FONDECYT Project 1130096 on "Denominaciones de origen de productos agroalimentarios chilenos" ("Appellations of Origin of Chilean Food and Agricultural Products"). 


\section{Resumen}

P. Lacoste, D. Jiménez y N. Soto. 2014. Génesis e identidad del queso Chanco (Chile 17501860). Una contribución al estudio de las denominaciones de origen en América Latina. Cien. Inv. Agr.41(3):317-325. El origen del Queso Chanco en Chile en el periodo 1750-1850 es discutido. Al efecto, fueron estudiados los inventarios de ocho fábricas de queso registradas en los siglos XVIII y XIX, además de otras fuentes documentales. El queso Chanco era un queso cocido y maduro hecho principalmente de leche de oveja $\mathrm{y}$, en menor medida, de leche de vaca. La zona productiva original fue delimitada por los ríos Maule e Itata, localizada en el Valle Central de Chile. En los siglos XVIII y XIX fue reconocido como el mejor queso de Chile. Su producción y mercado se establecieron bien dentro de los dos primeros tercios del siglo XIX. Su fama le permitió obtener buenos precios de mercado. Fue comido en casi todo el país, desde Copiapó a Valdivia. También se hicieron significativas exportaciones del queso de Chanco aproximadamente a mediados del siglo XIX.

Palabras clave: Agroalimentos en Chile, denominaciones de origen, indicación geográfica, queso de Chanco.

\section{References}

Arancibia, P.N. 1827. Partición de bienes de Pedro Nolasco Arancibia. Santiago de Chile, December 2. Archivo Nacional de Santiago de Chile (AN). Fondo Judiciales de Santiago (FJS). L 55. P 8. F 28.

Aravena, P.P. 1814. Tasación de bienes de don Pedro Poncio Aravena. Nirivilo. February 3. AN. Fondo Judiciales de Cauquenes (FJC). L31. P 9. F22 v.

Barra, B. 2006. Arrieros en el partido del Maule (1700-1750). Universum 21:12-27.

Bauer, A. 1930. La sociedad rural chilena. Desde la conquista española a nuestros días. Andrés Bello. 305 pp.

Bobadilla, J. 1821. Tasación de bienes de José Bobadilla. Estancia Yale Yale. February 20. AN. FJC. L 35. F 8 .

Cáceres, J.L. 1818. Solicitud de autopartición de bienes de José Laureano Cáceres, Asiento de Codellina. November 14. AN. FJC. L 33. P 4. F13.

Carrasco, P. 1805. Partición de los bienes de Pedro Carrasco. Asiento de Tapar. Distrito de Cuynome, Partido de Cauquenes. March 15. AN. FJC. L 25. P 4. F 1-4v.

Cobos, M.T. 1989. La división político administrativa de Chile, 1541-1811. Universidad Católica de Valparaíso. Chile. 174 pp.
De la Barra, F. 1773. Inventario de bienes de Fermín de la Barra. Villa de Cauquenes. 14 July. AN. FJC. L 2. P 11. F 3v.

Gay, C. 1862. Historia Física y Política de Chile. Agricultura. Tomo I. Museo de Historia Natural de Santiago. Chile. 482 pp.

Hidalgo, F. 1845. Inventario de bienes de Francisco Hidalgo. Santiago de Chile. AN. FJS. L 496. P 11. F 5v.

Lacoste, P., D. Jiménez, P. Aguilera, A. Castro, and N. Soto. 2014. The Awakening of Pisco in Chile. Ciencia e Investigación Agraria 41:449-473.

Pszczólkowski, P. 2014. "Terroir” y "Climats”: ¿realidad o quimera? / "Terroir" and "climats": reality or mirage? Revista Iberoamericana de Viticultura, Agroindustria y Ruralidad (RIVAR) $1: 13-19$.

Leal Pino, C. 2013. Disposiciones Colegio Apostólico de Propaganda Fide de San Ildefonso de Chillán. Primera parte: 1764-1779. Publicaciones del Archivo Franciscano. Chile. 188 pp.

Mena, J. 1811. Inventario de bienes de Juan Mena. Paraje Agustín Sánchez. March 6. AN. FJC. L 2. P 29. F 8ss.

Molina, J.I. 1987. Ensayo de la historia natural de Chile. Ediciones Maule. Chile. 383 pp. 
ODEPA. 2014. Series de tiempo de productos por planta o región de la industria láctea en Chile (2002-2014). Available online at: http://www. odepa.cl/series-de-tiempo-de-productos-porplanta-o-region-de-la-industria-lactea/ (Website accessed: April 15, 2014).

Opazo, F. 1820. Inventario de bienes de don Francisco Opazo. Asiento de Numen. January 17. AN. FJC. L 35. P 4. F 10v.

Pinochet de la Barra, O. 1979. Los Pinochet en Chile. Siglo XVIII. Editorial del Pacífico. Chile. 175 pp. Retamal Ávila, J. 2006. Economía y sociedad en el Maule Sur en el siglo XVII. Estudios Coloniales IV. Santiago, Universidad Andrés Bello. p. 77-145.
Ribeiro de Almeida, A. 2010. A Autonomia Jurídica da Denominacao de Origem. Wolters Kluwer/ Coimbra Editora. Portugal. 1475 pp.

Rigaux, E. 2008. La leche, la manteca y el queso. Maxtor. España. 144 pp.

Sociedad Nacional de Agricultura. 1869. Fabricación de quesos (parte I). Boletín SNA 6: 113-116.

Sociedad Nacional de Agricultura. 1870. Fabricación de quesos (parte II). Boletín SNA 7: 132-135.

Valdebenito, P. 1814. Testamento de don Pascual Valdebenito. Villa de Chanco. January 25. AN. FJC. L 31. P 14. F 6 v. 
